\title{
Hegemonic conflict in the Caspian region: Accumulation by dispossession and the spatial fix
}

\author{
Patrick L. Ehland \\ West Virginia University
}

Follow this and additional works at: https://researchrepository.wvu.edu/etd

\section{Recommended Citation}

Ehland, Patrick L., "Hegemonic conflict in the Caspian region: Accumulation by dispossession and the spatial fix" (2010). Graduate Theses, Dissertations, and Problem Reports. 884.

https://researchrepository.wvu.edu/etd/884

This Thesis is protected by copyright and/or related rights. It has been brought to you by the The Research Repository @ WVU with permission from the rights-holder(s). You are free to use this Thesis in any way that is permitted by the copyright and related rights legislation that applies to your use. For other uses you must obtain permission from the rights-holder(s) directly, unless additional rights are indicated by a Creative Commons license in the record and/ or on the work itself. This Thesis has been accepted for inclusion in WVU Graduate Theses, Dissertations, and Problem Reports collection by an authorized administrator of The Research Repository @ WVU. For more information, please contact researchrepository@mail.wvu.edu. 
Hegemonic Conflict in the Caspian Region:

Accumulation by Dispossession and the Spatial Fix

Patrick L. Ehland

\begin{abstract}
Thesis submitted to the
Eberly College of Arts and Sciences

At West Virginia University

in partial fulfillment of the requirements for the degree of
\end{abstract}

\author{
Master of Arts \\ In \\ Geography
}

Graduate Committee

Dr. Robert Q. Hanham, Ph.D. (Chair)

Dr. Brent McCusker, Ph.D.

Dr. Timothy Warner, Ph.D.

Department of Geology and Geography

Morgantown, West Virginia

2010

Keywords: Uneven Development, Accumulation by Dispossession, Hegemonic Conflict, Spatial Fix, Caspian Region 


\section{ABSTRACT \\ Hegemonic Conflict in the Caspian Region: Accumulation by Dispossession and the Spatial Fix}

\section{Patrick Ehland}

This research examines the political-economic and military activities of three major powers, the United States, China and Russia, in the Caspian region, comprising the nation states of Kazakhstan, Turkmenistan, Uzbekistan, Tajikistan, Kyrgyzstan, and Azerbaijan, since the collapse of the Soviet Union in 1991. The activities of these three powers have been guided primarily by resource and strategic needs, and they have had a significant effect on the uneven development of the Caspian states. The interests and actions of the three powers have frequently come into conflict with each other, and the responses of the individual Caspian states have varied widely. The research uses Harvey's concepts of the spatial fix and accumulation by dispossession and Arrighi's concept of hegemonic decline and conflict to understand the uneven development of this region. 


\section{ACKNOWLEDGEMENTS}

I would like to take this time to thank my adviser, Dr. Robert Hanham, as well as the rest of my committee, all have offered unique and critical insight and help in the completion of this thesis. This thesis is the result of many hours of research and labor, and reflects the dedication my committee has. I would also like to thank my wife and family for their love, patience, and support through this task. 


\section{Page}

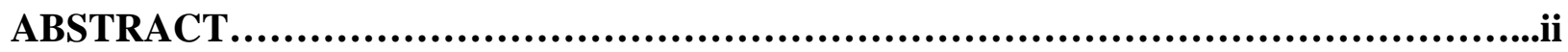

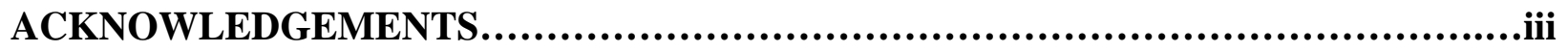

TABLE OF CONTENTS ......................................................................

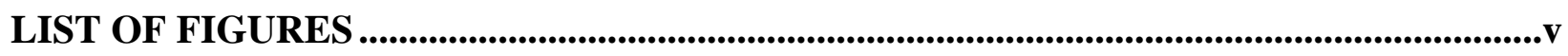

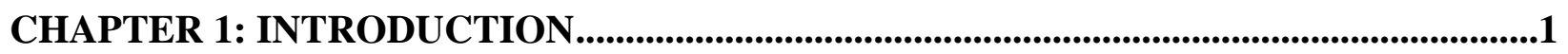

CHAPTER 2: CONCEPTUAL FRAMEWORK ..............................................................5

CHAPTER 3: OVERVIEW OF HEGEMONIC CONFLICT.......................................................8

CHAPTER 4: HEGEMONIC CONFLICT IN STRATEGICALLY IMPORTANT

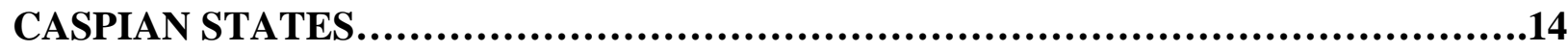

CHAPTER 5: HEGEMONIC CONFLICT IN ENERGY RICH CASPIAN STATES..........23

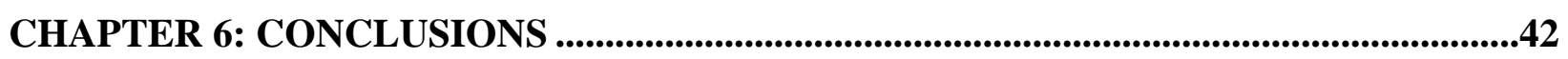

REFERENCES................................................................................................................................... 44

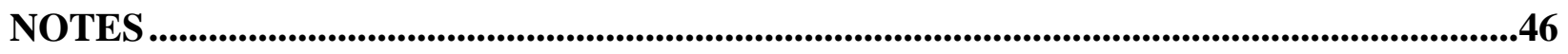




\section{LIST OF FIGURES}

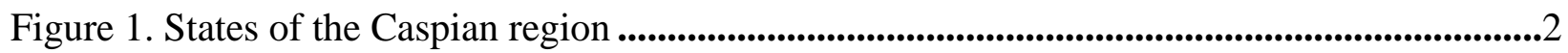

Figure 2. Afghan poppy trade routes .................................................................................22

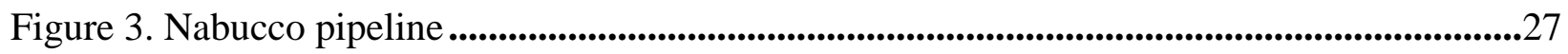

Figure 4. Baku pipelines, current and proposed ........................................................................332

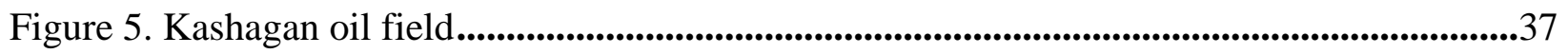

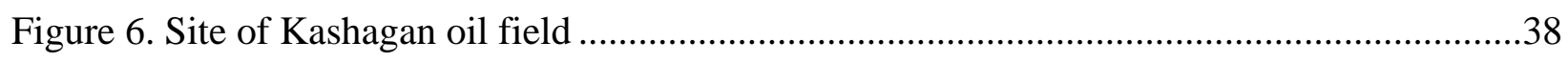

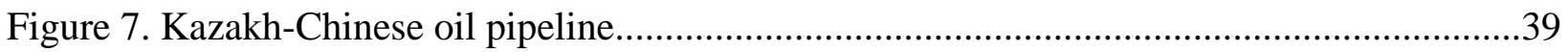




\section{CHAPTER 1: INTRODUCTION}

The collapse of the Soviet Union in 1991 brought major changes to the geopolitical landscape. The Cold War was over, and the United States was the new dominant hegemon in the world. The US saw its new position as the undisputed leader to further its own goals and reinforce its power. The neoliberalist approach of the US and the Western world, championed by Reagan and Britain's Thatcher, and continued by George H.W. Bush and then Bill Clinton saw a rising tide of American influence across the globe. The free market ideology of neoliberalism has been a driving force of economic globalization since the 1980s, which has allowed the US and US corporations to profit from access to cheap labor and resources.

The US has long been the world's leading consumer of gas and oil, but globalization has greatly increased the demand for fossil fuel energy resources in emerging East Asian economies, India, and an expanding European Union. The race to control access to oil and gas resources is a topic that will be addressed in this thesis, and in particular how the United States, China, and Russia have fought to address their energy needs in the Caspian region.

The Soviet collapse resulted in the establishment of a number of newly independent republics in Central Asia, loosely organized under the banner of the Commonwealth of Independent States, which remained under Russian influence in the immediate aftermath of the collapse. The switch from planned economies to free market capitalism was difficult. International corporations and governments soon began to see potential in these new resource rich countries. Energy corporations sought access to the potential extensive oil reserves in Azerbaijan and Kazakhstan, and huge gas potential in Turkmenistan and Uzbekistan. Exxon, Shell, (Russia’s) LukOil, and (Italy’s) Agip soon had specialists in the region to establish prospects and potential contract rights. The rise in energy prices in the 2000s contributed to the 
rapid intensification of land rights, project developments, and exploration activity in the region by the United States, China, and Russia, resulting in massive profits. These three countries, referred to in this thesis as the Big Three, all have elaborate stakes in the Central Asian region, particularly in and around the Caspian Sea. The states of the Caspian region, Kazakhstan, Turkmenistan, Uzbekistan, Tajikistan, Kyrgyzstan, and Azerbaijan (see Figure 1), all have

Commonwealth of Independent States - Central Asian States

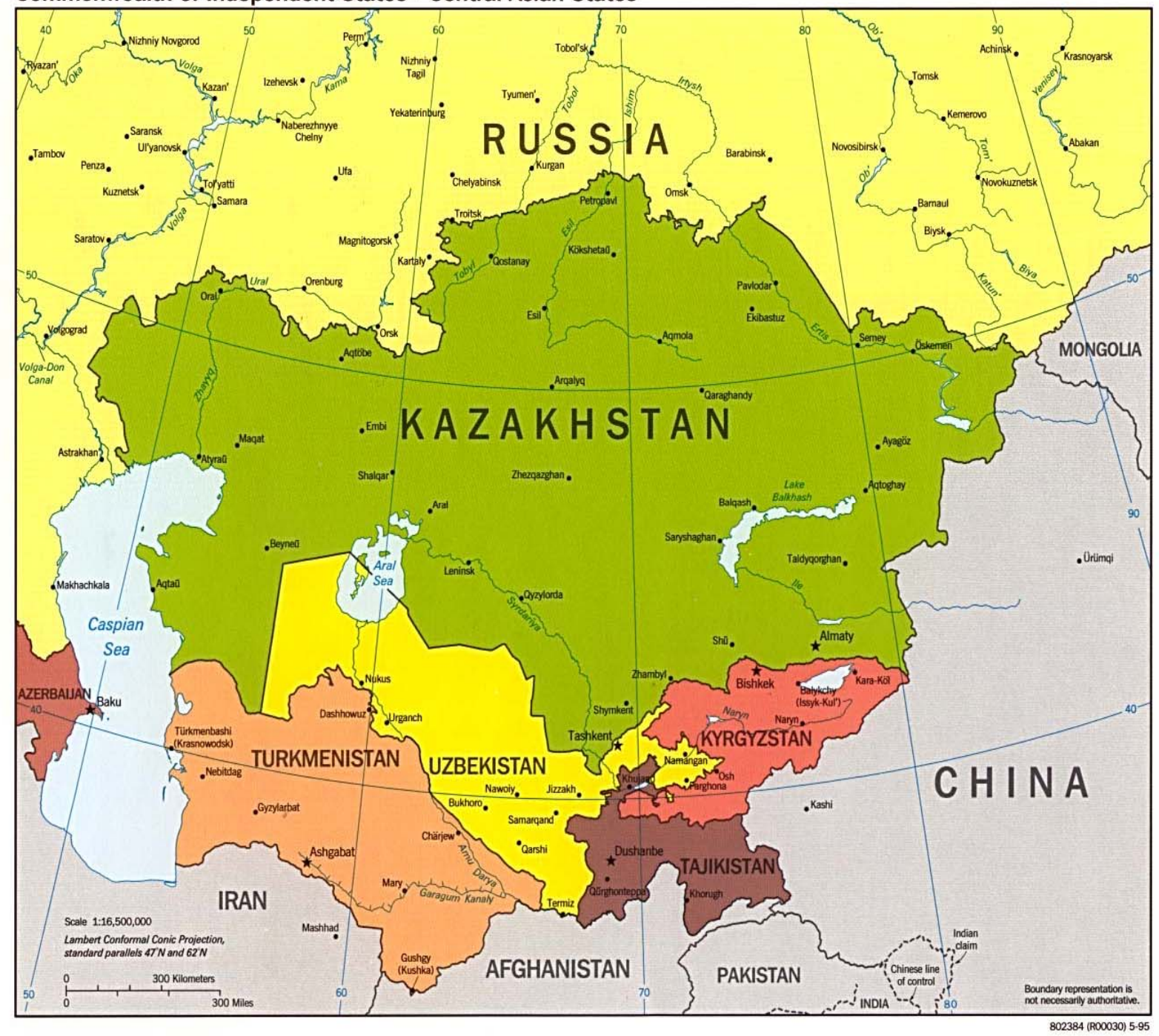

Figure 1: The States of the Caspian Region ${ }^{1}$ 
experienced dramatically increased international focus and have faced unique development consequences from this. The effects of this development have been unevenand, more recently, fluctuating and unstable, especially since the onset of the very recent global economic downturn.

Russian author Alexander Dugin, who subscribes to a Russian-based neolibearlist philosophy, feels that the collapse of the Soviet Union in no way should change the influence it has over the Caspian states (Shlapentokh 2007). Current Russian Prime Minister Vladimir Putin has also stated repeatedly that Russia should remain the dominant power in the region. China, with its rapidly growing economy has also made numerous agreements to gain access to the resource rich region. While locating official Chinese documentation is near impossible, it is evident that Central Asia will remain a major energy interest for the Chinese.

How the Big Three, and increasingly the EU, will continue to invest in the Caspian states will hinge on two major issues: the ever-fluctuating prices of oil and natural gas, and secondly the global economic crisis. The rapid downturn of the global economy, and of credit markets in particular, have all impacted the Big Three to varying degrees. The US has experienced a wave of financial collapses as dozens of banks and holding companies have failed, taken over by others, or received government subsidies. The housing bubble burst, coupled with the Wall Street collapses aided were the catalyst for the global credit crunch. The sudden drop in the price of oil has also created another crisis in the Russian Federation. Russia had been riding the soaring prices of oil to new heights since 2005. However, since the credit collapse in the second half of 2008, Russia was hit especially hard. The leading stock market, the RTS, has lost approximately 54\% since July 2008 (Business Week, 2008). The Chinese economy has also slowed, although much less so, as cutbacks in projects and bank failures have taken their toll. Perhaps the hardest hit are the Caspian states. 
The general goal of this thesis is to improve understanding of hegemonic conflict and uneven development in the energy resource-rich Caspian region. More specifically, the objectives of the thesis are to: (1) to conceptually link Harvey's (2006) theories of 'accumulation by dispossession' and the 'spatial fix' to 'hegemonic conflict', a concept derived from the work of Arrighi (2005), and (2) to examine how these linked concepts allows us to better understand the uneven development of the Caspian states and the role played by the struggle between the United States, Russia and China for access to oil and natural gas in the region.

The rest of the thesis is organized as follows. Chapter 2 summarizes the conceptual framework of the study, based on the work of Harvey and Arrighi. Chapter 3 presents a general overview of hegemonic conflict in the Caspian region. Chapter 4 provides a detailed description of how hegemonic conflict has been played out in three strategically important states of the Caspian region, Uzbekistan, Tajikistan, and Kyrgyzstan. Chapter 5 provides a detailed description of how hegemonic conflict has been played out in three energy rich states of the Caspian region, Kazakhstan, Turkmenistan, and Azerbaijan. Chapter 6 presents some conclusions of the study. 


\section{CHAPTER 2: CONCEPTUAL FRAMEWORK}

This chapter summarizes the conceptual framework used in the study. The general framework used here is Harvey’s conceptualization of uneven development, (Harvey, 2006). Particular attention is given to two components of uneven development. The first is Harvey’s concept of accumulation by dispossession, which he argues is a key component of uneven development. The second draws upon Arrighi’s (2005) work on hegemonic conflict and the use of the spatial fix by declining hegemonic powers, such as the US. The concrete context of the study is the struggle for energy resources in the Caspian region.

Harvey (2006) argues that there are four conditionalities in a unified theory of uneven development. These conditionalities are:

1. The material embedding of capital accumulation processes in the web of socio-ecological life.

2. Accumulation by dispossession.

3. Accumulation in space in time.

4. Political, social, and class struggles at a variety of geographical scales.

The first conditionality argues that capital accumulation entails the commodification of every aspect of daily life. Accumulation processes are therefore grounded in the space of everyday life. These processes both work through and transform the social relations in society. Capitalist activity is simultaneously in constant search of new arenas, while also being grounded in space.

The second conditionality argues that accumulation by dispossession is a key process of uneven development. Accumulation by dispossession goes beyond the traditional view of accumulation as the appropriation of surplus of labor by capitalists (i.e. expanded reproduction), 
to argue that accumulation also takes place through the dispossession of other people's assets. Harvey (2006) and Arrighi (2005) both argue that dispossession has been an increasingly important form of accumulation during the neoliberal, globalization phase of capitalism since the 1980s. Dispossession itself can occur in many different forms. These range from outright military action, to more covert operations like structural readjustment, or privatization. Harvey also argues that uneven development through dispossession is critical for the stability of capitalism. Finally, Harvey makes the case that it is the state which plays the dominant role in enforcing accumulation by dispossession (Harvey, 2003).

The third conditionality refers to the processes of accumulation which occur through space and time. Accumulation results in spatial competition, the creation of a spatial division of labor, the annihilation of space through time, the need to fix capital in space, the production of scaled regions, the creation of alliances to protect the interests of the various parties who are fixed in space, and attempts to resolve crises of overaccumulation by means of a spatial fix.

The fourth conditionality refers to the political, social, and class struggles over accumulation at a variety of geographical scales. Such struggles can involve a wide range of participants, from social movements to insurgent, ethnic, religious, and class-based groups. These groups may be driven by either internal forces or by external forces. A good example of this distinction in the case of the Caspian region are attempts by local groups to assert sovereignty or independence in the new Caspian states and attempts by external forces (e.g. the US) to manipulate local conditions to gain access to resources. For example, one could interpret the so-called 'Color Revolutions' as attempts by citizens to create their own identities by throwing off the stigmas of old regimes with the promise of change. However, Shlapentokh quotes Russian political figure Dugin as interpreting these revolutions of just the opposite, that 
these were in fact regime changes brought on by the US and Europe to allow easier access to regional assets (Shlapentokh 2008).

The second conceptual component of this research draws on the work of Arrighi (2005). Arrighi argues that Harvey’s concept of the spatial fix is not simply a strategy used to overcome crises of overaccumulation. It is also an aggressive strategy increasingly used by declining hegemonic powers in conjunction with accumulation by dispossession, and one which results in increasingly serious resistance. Arrighi demonstrates how the US’s search for a spatial fix has caused significant 'blowback' in other parts of the world, as witnessed by the invasions of Iraq and Afghanistan. The US's military presence in South-Central Asia is a spatial fix to profit from the world’s largest oil and gas reserves. Being a spatial fix, it involves a fixed, long-term presence in the region, which has to be enforced by military occupation. Arrighi argues that the US no longer has the economic strength to enforce the spatial fix, but must increasingly rely on methods which result in worsening blowback. Russia does not want to see its former sphere of influence challenged, and China is seeking to expand its influence in the region. The US established diplomatic relations with all of the Caspian states immediately after the dissolution of the Soviet Union in 1991, and it stepped up its interests in the region after 9/11. Russia has an inherent interest in the region for both security and resource reasons, and its desire to keep other powers out of their former empire is well known (The Economist, 2008). China's economy has been growing impressively over the past two decades, and its energy demand reflects this. With the world's largest population, and growing economy to match, the Chinese also have plenty to gain by securing rights to the energy potential of the Caspian region. 


\section{CHAPTER 3: A GENERAL OVERVIEW OF HEGEMONIC CONFLICT IN THE CASPIAN REGION}

The Caspian states themselves are comprised of Kazakhstan, Turkmenistan, Uzbekistan, Tajikistan, Kyrgyzstan, and Azerbaijan. These states form a vast region of Asia, and sit atop some of the world's richest deposits of natural resources. The region has one of the longest, and richest histories in recorded human history. Thought to have had human population as far back as 40,000 years $^{2}$, the region has also been synonymous with struggle for its control. Civilizations that have fought over this vast area include the Chinese, Mongol, Persian, Macedonian, Turkish, and even Arab expansion. More recently, conflicts over independence were fought in the early Imperial Russia, ultimately leading to Soviet rule by the mid-1920s. The region was also a target during the “Great Game” period of European colonialism. However, after the Bolshevik Revolution, the territory was officially into the new Soviet Union.

Under Soviet dominance, the Caspian states underwent numerous administrative shakeups. The region was initially one large political district. The Turkestan Autonomous Administrative Soviet Socialist Republic was founded on April 18, 1918, its capital Tashkent with a population of five million. In 1924, the district was divided into five distinct republics: Tajik ASSR, Turkmen SSR, Uzbek SSR, Kara-Kirghiz Autonomous Oblast, and Karakalpak ${ }^{\mathrm{i}}$ Autonomous Oblast. In 1926, the Kara-Kirghiz Oblast was divided under orders from Joseph Stalin, becoming the Kirghiz SSR. In 1936, the Kazakh SSR was established, incorporating regions from the Kirghiz SSR. Several other ethnic-based Soviet republics managed to escape incorporation into larger republics. However, this would not last for long.

As a means of controlling potential ethnic conflict, the Soviet administration in Moscow again redrew the political boundaries of the region, beginning in the late 1920s. This project was 
headed by then-Commissar of Nationalities, Joseph Stalin, to nationally delimit the Soviet Union. The project began in 1922 and was completed in 1936. As a result, the Caspian States were granted full autonomous status as members of the fifteen total constituent Soviet Socialist Republics (SSRs). For reference, the SSRs in this discussion are the Kazakh SSR, Tajik SSR, Kirgiz (also known Kyrgyz SSR), Uzbek SSR, and the Turkmen SSR. It should also be noted that the Azerbaijan SSR will become important in later discussions.

The Caspian region is landlocked, mostly dominated by arid steppe, with several deserts, as well as two major bodies of water: the Caspian and Aral Seas. In fact, Uzbekistan is one of only two countries on Earth to be doubly-landlocked (the other being Liechtenstein). The region experiences dramatic weather. Temperatures in winter dropping as far as -90 degrees Fahrenheit are not unheard of, and can reach well into the 110s in the summer. Savanna grasslands mainly dominate the steppe, although coniferous forests exist.

Soviet control of the region resulted in varying degrees of development. The Soviet Army used ancient outposts and established bases throughout the region to quell potential religious unrest. In addition, the political boundaries established cut through ancient ethnic lines. However, due to the remoteness and rugged terrain, the republics were not as susceptible to changing political climates in Moscow as other parts of the Soviet Union (e.g. the Ukraine, the Baltic States, etc.). This made central economic planning that much more difficult for the Kremlin. This had the unintended consequence of allowing the populations of these republics to retain a far greater amount of traditional heritage and culture. However, Soviet leadership mandated that each republic simultaneously retain its own history, but stress the importance of the Soviet connection. Historians feel the greatest direct impact of Soviet rule in the Caspian 
states came in the 1979 invasion of Afghanistan ${ }^{3}$. The invasion and subsequent ten-year war had a strong ripple effect on the region.

With Gorbachev’s policies of glasnost and perestroika, the Soviet Union’s influence started to decline. A rapid sequence of events began in 1990 with the declarations of independence of the Baltic States. Deteriorating domestic political crises ultimately led to the attempted coup in August 1991 and Gorbachev's subsequent resignation essentially led to the dissolving of the Soviet Union. Before Christmas of 1991, each autonomous republic of the former USSR had declared its independence. The result was fifteen new countries comprising the Commonwealth of Independent States (CIS).

Each of the new republics of the CIS has dealt with its independence in various ways. Some have reached out, and made attempts at allying themselves with the West. These include Georgia the Baltic States (Estonia, Latvia, and Lithuania), the Ukraine, and Moldova. The Caspian states have pursued differing political agendas, each branching out in several different paths. Those closer to China, like Kyrgyzstan and Tajikistan, have moved to a more Chinese sphere of influence. Kazakhstan retains a major Russian influence, but has also experienced interest from by US and Chinese. Others, like Uzbekistan and Turkmenistan's intentions remain unclear. Their respective governments have both deftly manipulated and ostracized themselves from major international interests. They are also home to some of the some of the worst offenders of human rights in the world.

The geopolitics of this region has been dubbed “The Next Great Game” (Sandole 2007). “Traditionally, this 'game' has been played between the British and Russian Empires, but now it is primarily between the United States, Russia, and China. The US is pushing for democratic transformation, which the Chinese and Russians view as antithetical to their goal of achieving 
and maintaining stability in the region” (Sandole 2007; Schmidle 2006; Weiss 2005; Zeigler 2007). Another factor to this is the potential "partnership" between Russia and China to keep the US/NATO expansion out of the region.

It is here where the concept of accumulation by dispossession is useful in analyzing the region. Each of the Big Three have varying degrees of investment in the energy reserves of the region. Additionally, multinational energy corporations have established their own individual presences in the region as well. Oil companies such as BP, Agip, Exxon, and Shell have all closed lucrative contracts for oil rights in Azerbaijan and Kazakhstan (LeVine 2007; Stulberg 2007). Russian state-owned LukOil also has rights to Kazakh and Azeri oil fields in the Caspian Sea (Stulberg 2007). Turkmenistan has allowed all three to explore gas reserves, as well as granted German and British firms access as well. Kazakh-owned KazMunaiGas has also purchased smaller, independent firms in March $2008^{4}$. The Big Three have also proposed numerous trade agreements with all states in the region (Bayulgen 2005). The United States has recently ramped up efforts in Kyrgyzstan to keep the balance of power after its dismissal from an Uzbek airbase due to criticism of the Andijan massacre in 2005. Central Asia is the most likely area of potential confrontation between Russia and China, "especially Kirgizia (Kyrgyzstan) and Kazakhstan, which will be the earliest target of the Russian-Chinese confrontation” (Shlapentokh 1995). Turkmenistan was invited by the United States to the April 2008 NATO summit in Bucharest, where fellow CIS members Ukraine and Georgia were denied approval for acceptance into the treaty bloc.

The Caspian region is a primary target in the search for the next global spatial fix. With the increased demand for energy, it comes as no surprise that the Big Three have increased their attention to the region, though it can be argued that Russia never stopped. These states are 
considered "weak" in terms of GDP and population living at or below the poverty line (Tsygankov 2007). The key to the spatial fix in this area will be pipelines, and who controls them. Pipelines are essential in energy reserve extraction. Landlocked and remote, the only method of transportation of the energy reserves are networks of pipelines. It comes as no surprise then, that the IMF gave $\$ 1.5$ billion in startup investment fund to Kazakhstan in 1994, in exchange for American and European oil businessmen to meet with both Russian and Kazakh officials to open discussions over the exploration of the Tengiz oil field (LeVine 2007; 257-8). Additionally, the World Bank was critical of oil firm Unocal's business practices in negotiations in Turkmenistan, Afghanistan, Pakistan, and Uzbekistan over natural gas pipelines. The World Bank, on behalf of the US, Britain, and Russians, complained that Unocal was given preferred treatment over rights to pipelines by manipulating local politicians and tribal leaders (LeVine, 2007, 297-98). The US also backed off previous denouncements of the human rights situation in Turkmenistan. It has also strengthened ties in Kyrgyzstan to secure a military presence in the region. A former US National Security Advisor declared the region "pivotal" to US interests, but "other great powers too have been eager to expand their influence after the breakup of the Soviet state” (Tsygankov 2007). The Chinese have recently announced major investment projects in Kazakhstan, Tajikistan, and Kyrgyzstan. Russia remains the main trade partner with both Uzbekistan and Kazakhstan.

These facts tie into Arrighi's argument of hegemonic decline. He indicates that the foreign policy of the United States, dictated by the 'Project For a New American Century', has sought to establish a quasi-American empire. The US aims to do this by opening markets and promoting the financialization of the US economy. Arrighi invokes Harvey's theories of overaccmuluation as a critical challenge which the US faces to this end. The current downturn in 
the US economy, resulting from the credit crisis, has now become a global problem. The Russians also experienced an economic crisis in the late 1990s, which ultimately led to Yeltsin resigning and turning the country over to Vladimir Putin in 1999. (Rasizade 2008). Much like the 'Project For a New American Century', which plays upon nationalism and the importance of an American-dominated globe, Alexander Dugin is calling for the same in Russia. A Russian intellectual and politician, Dugin has reestablished the concept of Eurasiansim, where Russia becomes the dominant power in both Europe and Asia. The first step to this is reclaiming political and economic control of Central Asia, and secondly, to keep Chinese and Indian interests out (Shlapentokh 2007). The Chinese have no plans of easing their economic expansion, however, although they are also experiencing the fallout of the global credit crunch. Their spatial fix includes looking westward, and involves investments in the Caspian states (Tookey 2007). Finally, it must be acknowledged that the Caspian states themselves have their own agendas and goals which they wish to pursue, with or without global power assistance. 


\section{CHAPTER 4: HEGEMONIC CONFLICT IN STRATEGICALLY IMPORTANT CASPIAN STATES}

Since the early 1990s, the Big Three have sought to expand their hegemonic goals in strategically important members of the Caspian states. These are the countries of Uzbekistan, Kyrgyzstan, and Tajikistan. These three do not have the rich energy reserves of the other Caspian states, but their location has made them important to the Big Three in their geopolitical goals. Using the policy of the War on Terror and claiming to spread freedom across the globe, the US has taken a very increased interest in the Caspian states. The invasion and occupation of Afghanistan in October 2001 created a dire need of cooperation from the local states in Central Asia. However, critical look at the increase of US attention to the region goes further back. The United States sponsored, funded, and equipped many of the Islamic militants during the Soviet occupation of Afghanistan in the 1980s. With the Soviet withdrawal in 1988, the US’s geopolitical interest in Afghanistan waned. However, over the next eight years, Afghanistan experienced a devastating civil war which resulted in the establishment of the Taliban rule in 1996. The United States was at least indirectly responsible for the creation of the Taliban, and clearly responsible for the current situation. Since Afghanistan is landlocked, rugged, and remote, needing other governments in the region to allow access to military bases, infrastructure, and air space to conduct operations is essential.

\section{Uzbekistan}

While lacking the rich oil and gas reserves of its neighbors, Uzbekistan does have major gold deposits, as well as being one of the world's leading exporters of cotton. It is also an extremely important country of strategic importance. Uzbekistan’s incredibly repressive 
government was responsible for the Andijan massacre in 2005. The government of President Islam Karimov cracked down on growing political discontent across the country. The Uzbek government has repeatedly stated that the crackdowns were to quell growing Islamic radicalism, while critics argue that the government feared another potential "color revolution", several of which had occurred in the former USSR in the previous two years, including in neighboring Kyrgyzstan. The Andijan massacre was the most infamous event during these crackdowns. Government troops were attempting to break up a large crowd of demonstrators, when shots were fired. Whether the military or protestors who shot first remains unknown and extremely controversial, but estimated casualties range from government figures of nine ${ }^{5}$ to the Office for Democratic Institutions and Human Rights over $600^{6}$.

The United States State Department diplomatic reaction was very critical, suggesting that the incident may have been the result of terrorist actions, while Russia and China supported the Uzbek response. After pressure from a bipartisan group of US senators who wanted to open United Nations investigations and inquiries, the State Department considered cutting diplomatic ties. The US Department of Defense, specifically Secretary Donald Rumsfeld, suggested a more tempered response, but the damage was done. This sparked a major shift in Uzbek foreign policy, which was mostly neutral, to a much more pro-Russian stance. As a result of the US's condemning of the events, Karimov revoked the US's lease of the Karshi-Khanabad airbase ${ }^{7}$. This left the Manas airbase in Kyrgyzstan as the only remaining base with US forces in the region. However, in March 2008, the US backtracked on its previous denouncements. The result was Uzbekistan readmitting US use of the airbase. 
The Uzbek government has since strengthened economic and diplomatic ties with Russia and China, showing evidence of the shifting hegemonic contradictions in this region. To counter this, the US stepped up ties in Kyrgyzstan.

Kyrgyzstan

Kyrgyzstan was largely ignored by Moscow throughout its years as a Soviet republic, and remained so after independence. The US, however, did give hundreds of millions of dollars in aid with the Freedom Support Act passing in 1992. The US and China also helped develop Kyrgyzstan's vast potential hydroelectrical energy. The Tulip Revolution became the third, and currently most recent, of the color revolutions has drastically altered how the Big Three have approached the country. Kyrgyzstan has since become a major wild card in the region. Despite not possessing significant quantities of mineral wealth, its strategic importance makes it a pivotal target for the Big Three’s hegemonic conflict.

President Askar Aliyev had reached his term limit in 2005. However, his son and daughter were both in countrywide elections for parliamentarian positions, scheduled for March 13. This sparked unease, as Kyrgyz citizens feared a dynastic government forming. Both children won their seats, in addition to widespread reports of voter fraud. Demonstrations and civil unrest broke out in southern cities, notably Osh, eventually spreading nationwide. Military and police attempted to quell the demonstrations, but this only added to the fervor as rival political leadership joined. Aliyev stated he would not step down, nor discuss the situation with the protestor’s leadership. By March 21, opposition political leader Roza Otunbaeva, herself a former prime minister, stated that police and military were defecting in massive numbers ${ }^{8}$. Three days later, the protests reached the capital of Bishkek, and the opposition party became unified 
with former prime minister Kurmanbek Bakiyev and Otunbaeva the leaders. The same day, Aliyev and his family fled to Kazakhstan and then to Moscow, where he again refused to resign. As more protestors seized control of key political and military buildings and posts, political prisoners were freed. The Kyrgyz Supreme Court declared the election results invalid, and named Bakyiev acting president and prime minister. Clashes between pro-Aliyev supporters couple with some remaining government forces and the protestors caused many causalities while the new political leadership appealed for calm across the country. By March 28, relative peace had been reached across the country, with the previous parliament being dissolved and a new one established. Aliyev agreed to resign, formally stepping down on April 5. His resignation was adopted by the new Kyrgyz leadership six days later after debate on how he and his family's political powers should be dealt with, since the previous parliament had given them many privileges. One condition of his resignation was the forfeiture and stripping of all said privileges. The revolution was officially over when Bakyiev won a landslide in elections held in July. Bakyiev appointed Felix Kulov, a leading opponent of Aliyev and former political prisoner freed during the revolt, as prime minister.

Immediately after the revolution was over, reports that the United States had influenced the events began to surface. Money from the US from the Freedom Support Act, in addition to funds from other government-financed institution such as Freedom House and National Endowment for Democracy, Kyrgyz opposition leaders stated was essential in the regime change $^{9}$. Aliyev also suggested that the West had been actively trying to foment political and societal unrest. In addition, the Manas airbase, run by the US military since December 2001, did not report a single incident or interrupt during the entire revolution. Kyrgyzstan was clearly moving closer towards the US. However, within a year, these relations became strained. The 
political mood across the country had begun to darken, as the Bakyiev administration had begun to be accused of many of the same offenses Aliyev had done. These included nepotism, lack of developing infrastructure, disappearance of aid funding, rise in organized crime, and widespread corruption. In addition, the country became a major shipping route for opium grown in Afghanistan to other Central Asian countries. This resulted in a significant rise in violence and further corruption, especially in the south of the country. The situation reached a violent peak in summer 2006 when protests erupted in Bishkek resulting in the deaths of several parliamentarians. Bakyiev responded by saying political opponents were attempting a coup. Protests again broke out in mid-April 2007 in and around Bishkek over the worsening corruption, mafia violence, and narcotics problems. Government forces eventually broke up the demonstrations ${ }^{10}$.

The protests and violence caused a rift to develop between Bakyiev and the United States, and the Manas airbase became a focal point of controversy. Bakyiev threatened to close the base if the US did not pay more for troops to be stationed there. In December 2006, a US Air Force serviceman shot and killed a Kyrgyz truck driver waiting at a checkpoint. The US military has repeatedly stated the driver brandished a knife and the serviceman used deadly force in selfdefense. The Kyrgyz government and public were outraged and pushed for the immunity of the serviceman be lifted. The US military stated the serviceman would be retained on base until the matter was resolved, but it was later shown that he was evacuated despite the initial statements ${ }^{11}$. Bakyiev eventually stated on February 3, 2009 that the base would close, adding that economic considerations and negative public opinion of the US presence were part of the decision ${ }^{12}$.

With the shift away from the US, Kyrgyzstan announced it would be establishing a new joint economic partnership with Russia, and would be receiving \$2 billion in loans and another 
\$150 million in aid. Kyrgyzstan has also continued to strengthen its ties with China. The two have long had an energy partnership and in August 2007 signed a joint economic, military, and trade partnership. China had supported the Kyrgyz government's responses to the protests and demonstrations in 2006 and $2007^{13}$. From the vantage points of the Russians and Chinese, the renewed interest in Kyrgyzstan has be to seen a victory in taking a political and economic ally from the United States. From Kyrgyzstan's, they are receiving more aid and ties with powerful local powers. The US’s hegemonic accumulation by dispossession by keeping Kyrgyzstan close, especially with its strategic importance to Afghanistan as well as keeping China and Russia in check may have backfired by attempted to push a local government further than they wanted. The US may have been surprised by the opposition of a one-time ally.

\section{Tajikistan}

Tajikistan also continues to suffer from decades of neglect from the international community. The country was largely forgotten in the Soviet Union. Its rugged terrain, remoteness, and lack of exploitable mineral resources kept most Soviet-style development from ever reaching most of the country. The Soviets were able to do was pit the ethnic Tajiks against the Uzbeks in the republic. This would lay the foundation for much of the problems the country would face in the future. The collapse of the Soviet Union also ended whatever capital that was incoming from Moscow. Tajikistan’s ethnic tensions rose quickly and civil unrest became widespread. Despite its lack of resources available for export, Tajikistan, like its neighbors, did have strategic importance in the region. The US's hegemonic goals saw the US supporting and funding the anti-government forces. The resulting civil war wracked the country. 
The war began in the spring of 1992 when protests against the disputed presidential elections escalated into armed combat. President Rahmon Nabiyev and other high ranking government members disbursed weaponry and munitions to pro-government supporters and militias. Opposition parties and protestors acquired weaponry from Afghan warlords. The war itself was ethnic and regionally fueled, the Leninabadi and Kulyab against the Parmiris. The United States armed and supported several groups of the anti-government forces in ways similar to their support of the mujahideen during the Afghan civil war. Russia and Uzbekistan continued to fund and support the pro-government forces. The pro-government forces routed the opposition forces in the early stages of the conflict. The peak of the conflict reached its height between 1992-93, where the Kulyabi forces continued its military successes on the battlefield, and then began engaging in ethnic cleansing of opposing ethnic groups ${ }^{14}$. Mass killings, targeting of political figures, burning of villages, and the expulsion of rivalry groups were widespread in the south of the country. Tens of thousands of refugees fled to Afghanistan and Uzbekistan. Over the next several years, the opposition groups themselves fled into Afghanistan to recoup and reorganize. By now, Russian and Uzbek military forces were actively engaged in the war, which was increasingly becoming a stalemate for all sides. The breakdown in society, especially in the south, paired with foreign intervention fighting foreign Islamic militants stalled any real progress. By mid-1997, Tajikistan was in complete devastation and all sides had begun negotiating. Peace accords were signed in July 1997, ending the civil war. At least 50,000 were killed, and over 1.2 million were displaced ${ }^{15}$.

The Tajik civil war represented the worst kind of hegemonic accumulation by dispossession. Both the United States and Russia played roles in a foreign civil conflict to benefit themselves in some way. That the United States was attempting to further destabilize a former 
Communist regime with no tangible threat further shows the contradiction in hegemonic foreign policy. More recently, the Pentagon announced a new deal in early 2009 to promote economic development and help rebuild infrastructure. The civil war wrecked most of the country, and reconstruction has still been hampered in rural areas. Tajikistan also suffered from one of the harshest winters in history in 2007-08. Food shortages and widespread energy problems created further instability. Tajikistan's social and economic issues have given rise to a major increase in militant Islam and the country is a major shipping point for Afghan opium. The US's recent interest in the country was summed up as to "prevent the rise of another Afghanistan" (http://eurasianet.org/departments/insightb/articles/eav031609.shtml). The US wishes to keep Tajikistan relatively stable to maintain another local ally in a region they have few of. The strategic importance of Tajikistan makes it desirable to the US. Unfortunately, the civil war and subsequent years of underdevelopment have reduced it to a quasi-narco state, along with a strengthening of radical Muslim activity. Tajikistan accounts for 58\% of opium seizures in all of the Caspian states as well as almost a third of heroin seizures ${ }^{16}$ (see Figure 2).

The Chinese continue to invest capital in Tajikistan much in the way they have in Kyrgyzstan. Cheaper Chinese commodities are widespread in Kyrgyzstan, and have begun to appear in Tajikistan as well. Talks of a Chinese-funded hydroelectrical project in Tajik territory are also underway. The project would continue the construction of a dam which began as a Soviet project in 1976 and has only seen sporadic continuity since ${ }^{17}$. This would be the second Chinese-built dam in Tajikistan in two years ${ }^{18}$. Chinese investment may allow closer ties between the two. The results of foreign hegemonic interference will continue to add to the uneven development of the country for the foreseeable future. 


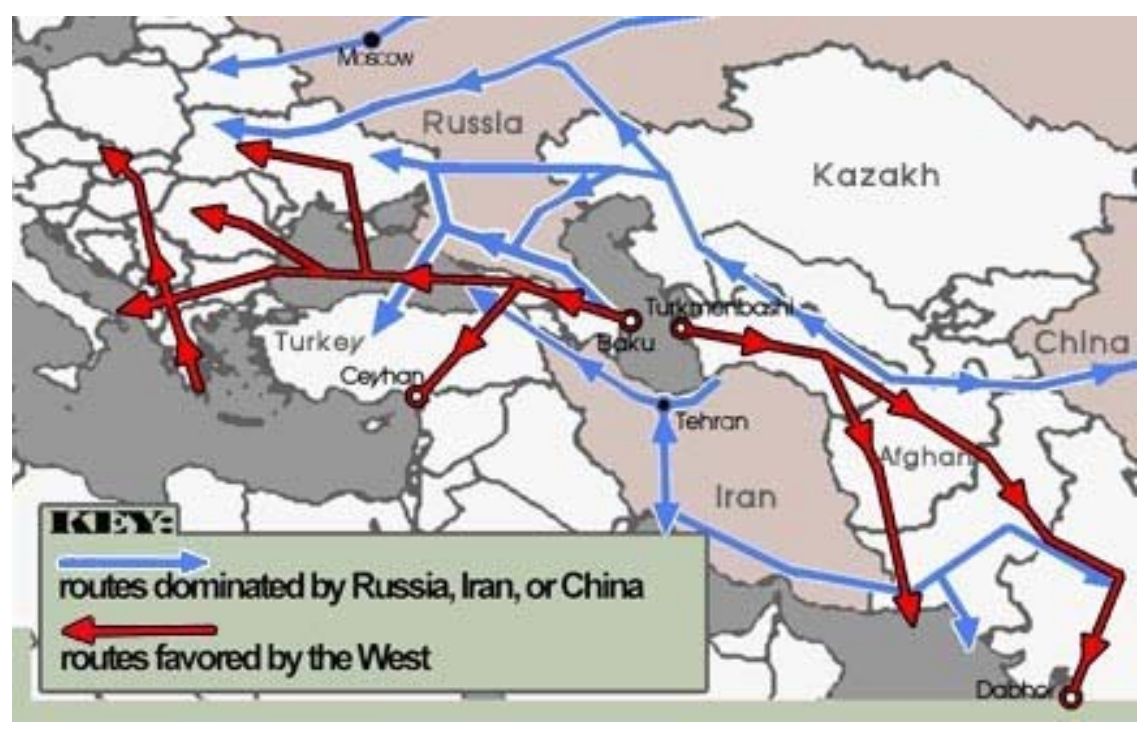

Figure 2: Afghan Poppy Trade Routes ${ }^{19}$ 


\section{CHAPTER 5: HEGEMONIC CONFLICT IN ENERGY RICH CASPIAN STATES}

This thesis will now move away from the geographically strategic states of the Caspian region and examine the uneven development implications of hegemonic conflict in the energy rich nations of the region, Turkmenistan, Azerbaijan, and Kazakhstan. These three have access to some of the richest reserves of energy resources in the world. The Big Three all have a vested interest in the development of each. The United States and China both have made major steps to procuring not just the drilling rights for the oil and natural gas, but also access to pipelines to get the resources to market.

\section{Turkmenistan}

Turkmenistan is an unknown in the Caspian states. From independence up until December 2006, the natural gas rich state was ruled by Saparmurat Niyazov. Autocratic and reclusive Niyazov established a Stalinesque cult of personality. Shortly after Turkmenistan’s independence in 1992, Niyazov was elected president (the only candidate on the ballot) and dubbed himself “Turkmenbashi”, literally “Leader of Turkmen.” In 1994, the Parliament extended him a 10-year term, and in 2002, declared him president for life.

The end of the communist system provided Niyazov the opportunity to promote his own image. His book, Ruhnama, became required reading in Turkmen schools. It promoted Turkmen culture and taught to reject international culture. It also established new holidays, many of which named after Turkmenbashi or members of his family. He actively promoted his cult of personality by erecting thousands of pictures and monuments to himself. The most notable of these is the solid gold, life-size statue of him located in the central square of Ashgabat which rotated to face the sun throughout the day. He amassed an estimated total wealth of $\$ 3$ billion at 
the time of his death, most "appropriated" from public funds ${ }^{20}$. Opposition parties were outlawed even before he was elected president. Public playing of music, opera, and theater were outlawed in the early 2000s. He sought several Soviet-style centrally planned economic development projects to jumpstart the economy, despite his suggestions that the country needed to move towards a free market economy.

During his reign, Turkmenistan did develop large scale industrial plants, drilling, and machinery to tap into the lucrative gas and oil reserves. Turkmenistan possesses the world’s fifth highest gas reserves, and second most in the former Soviet Union ${ }^{21}$. It also lays claim to the fifth largest natural gas field in the world, which was verified by British geologists in $2008^{22}$. Access to these reserves to other countries and international corporations kept the country from becoming completely isolated and ignored from the rest of the world. Niyazov did establish a permanent state of neutrality for Turkmenistan, which is recognized by the UN. He was able to play hegemonic powers off each other, sometimes with frustrating ease. Relations with Russia soured almost immediately after independence, especially after Niyazov supported the attempted coup in 1991. However, as time progressed, Russia was able to sway Turkmen gas exports and access rights towards themselves. This occurred because in the mid-90s the price of natural gas dropped significantly, and Turkmen capital began running out. Ashgabat began to seek interest in foreign investment, and Russia was willing to listen. Russia was then able to shift policy to their benefit, such as denying Turkmenistan access to pipelines to sell their gas to Europe. This remains a major point of contention in the region. Niyazov felt that the Russians had "robbed" his country, forcing him to accept prices $40-60 \%$ lower than he sought as well as having to pay not only access to pipelines, but also for equipment and services which rarely arrived on schedule or met quality specifications (Stulberg 2007). 
Turkmenistan’s options were hardly limited. The US-backed Trans-Caspian Pipeline (TCP), which would run from Turkey through Azerbaijan, throughout Turkmenistan, and reaching Pakistan has been scheduled for construction for over a decade. The route would bypass both Russia and Iran and offer Turkmenistan a prime outlet to European markets. However, after continued delays and logistical hang-ups, Niyazov's interest waned. Other potential pipelines included a route to Pakistan and India, as well as a Chinese-Japanese route. Despite progress made in every project, Ashgabat stepped back from each. Despite early indications that Turkmenistan was abandoning Russian regional control after independence, Western capitalist investors were increasingly frustrated with the seemingly contradictory stances Niyazov continued to pursue.

By the end of the century, and even though gas revenues were rising rapidly, Turkmenistan's strategic options continued to deteriorate. Russia had managed to hedge off potential markets by preempting gas sales to Europe by selling their own or buying it from other countries and reselling it. Years of impasse with Western developers kept US interest cautious at best. The Chinese expressed some interest, but progress was slow. To reach European markets, Ashgabat had to offer major concessions, as well as promising high volumes for delivery at cheap rates. Russia had managed to keep access to pipelines to every market in the region, including Turkey and Iran, out of Turkmen hands. This also kept future pipeline development in their favor by restricting access to and, in some cases, land rights. Russia eliminated many of Turkmenistan's demands, forcing Niyazov into further concessions. A key shift for Niyazov occurred in 2000-2001 when the price of gas skyrocketed from historic lows in the 1990s. Encircled by Russian influence, and fed up with potential Western investment, Niyazov began making extravagant demands to the Russians for their purchase of Turkmen gas. However, this 
was mostly grandstanding, and he was forced to make numerous concessions, including accepting only half payment in 2007 on potentially 2 trillion cubic meters of gas (Stulberg 2007). Perhaps the largest concession was the delimiting of access in the Caspian Sea. Niyazov was extremely careful to consult with Vladimir Putin before making any potential moves. Putin rejected Niyazov several times over issues such as off-sea drilling and establishing a Caspian Sea gas consortium. These shifts in policy represented a clear shift from Niyazov over such matters.

Niyazov's death on December 21, 2006 created a potential for major change in Turkmenistan. Turkmenbashi's personal doctor, little-known Gurbanguly Berdimuhamedow was appointed interim president on December 26, and won the presidential election in February 2007. He immediately promised to offer reform and deconstruct Niyazov’s personality cult. He quickly moved to reopen public theater and arts and sports, as well as establish the country's first internet café. He also ended the long musical and dance-filled pageants that opened and closed every official presidential meeting or visit. He also allowed non-ethnic Turkmens to return to work at posts where Niyazov had previously fired them. He reversed one of Niyazov's least popular moves by reestablishing pension funds for nearly 100,000 retired people. He has also changed calendar names back to their originals, and outlawed the right to rename places, monuments, and institutions after the president. He has said the gold statue in Ashgabat will be moved to a new location, though its ultimate destination is still unknown.

The change in leadership has also brought new developments to how the Big Three interact with Turkmenistan. Then-Russian president Vladimir Putin immediately held a summit the new president, while then- US Vice President Dick Cheney traveled to Ashgabat too. Western investors were also emboldened by the potential to finally reach terms to rights to drill or transport gas under a new regime. However, whatever optimism they may have had 
disappeared as no real progress was made through 2007. In 2008, at a summit to discuss further gas and oil developments, officials left disappointed, some frustrated by the apparent lack of cooperation from the Turkmen. The Turkmen officials refused to even refer to the potential Nabucco pipeline by name. The Nabucco pipeline is a planned pipeline stretching from Central Europe to Turkey, bypassing both Iran and Russia (see Figure 3). It would then link up with the planned Trans-Caspian pipeline. It is seen by the European and American governments as the most viable for reaching Turkmen gas. However, the reluctance of Turkmen officials to even acknowledge it by name left many confused and angry ${ }^{23}$. In addition, Russia had delayed the building of a gas pipelines to China the month before ${ }^{24}$. As such, it appears that Russia will continue to dictate how much of an influence Turkmenistan can exercise over the exporting of its gas reserves.

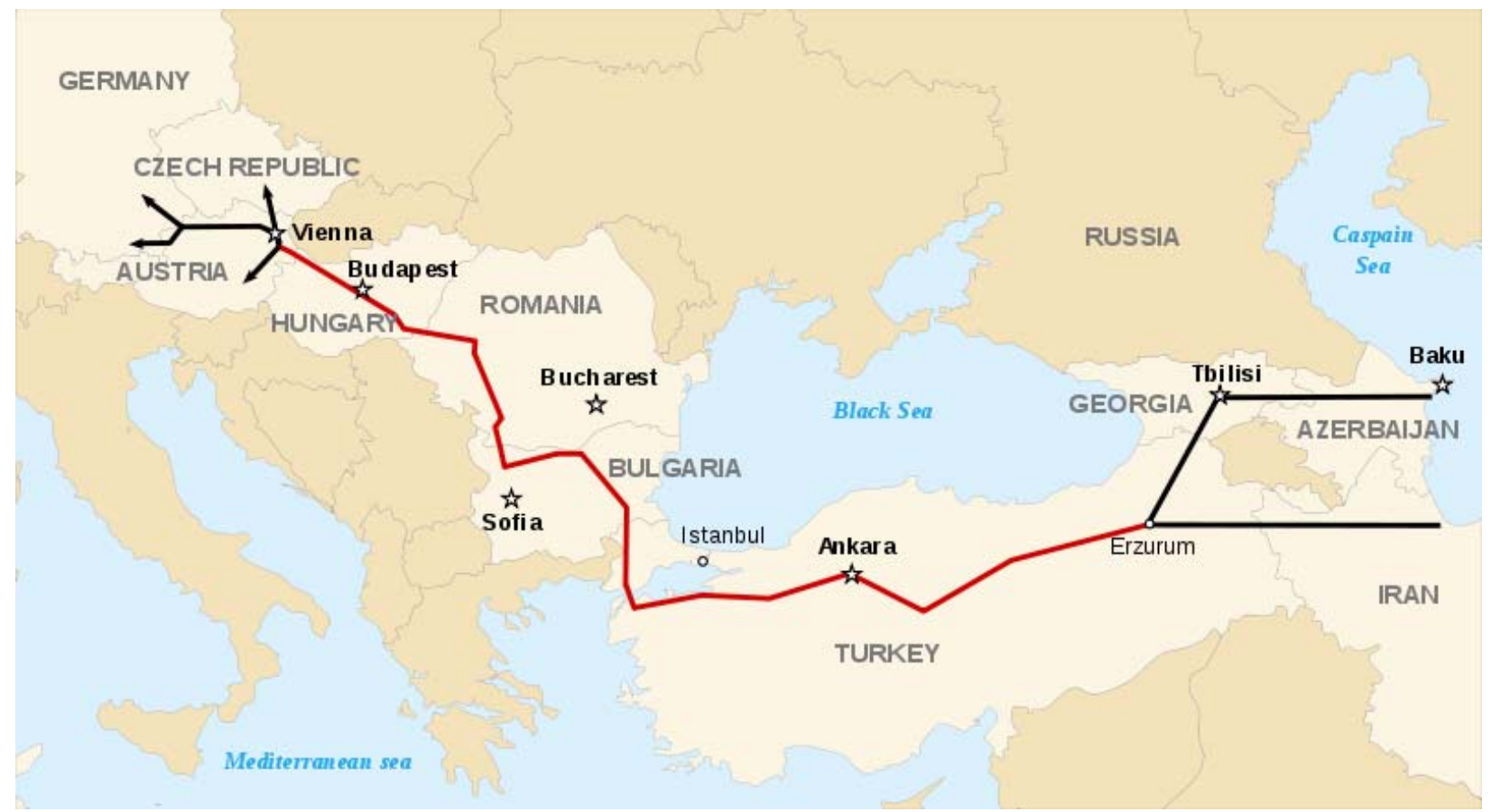

Figure 3: The Nabucco Pipeline ${ }^{25}$ 
Since the mid-1990s, the Russians have managed to almost completely choke off most potential outside investment of Turkmenistan. Because of their rich gas reserves, the Turkmen government established that the easiest way to economic development was exploiting these. However, after the Russians managed to keep the gas from reaching European markets by restricting access to the network of pipelines in the Caspian states, the Russians were able to dictate how much gas Turkmenistan could export. The Russians were also able to force Ashgabat to sell their gas to them at bargain basement prices, a clear example of accumulation by dispossession with implications for the uneven development of the country.

\section{Azerbaijan}

Azerbaijan experienced hegemonic influence earlier than any other country in the region. The history of foreign investment goes back to the 1870s. For centuries in and around the capital of Baku, residents were able to simply dig a hole in their yard and oil would rise to the surface. It was that rich and plentiful. Russia had long dominated the region. However, due to the vast oil reserves, foreign dollars and citizens flocked to Baku, creating a diverse and contemporary city. Many local residents became very wealthy in the oil business, and established a close-knit collection of barons who would in turn run the city. The richest and most well known of the local oil barons was Zeynalabdin Tagiyev. He made himself a fortune in the oil business, and was responsible for much of the construction of Baku (LeVine 2007).

Azerbaijan also had a tumultuous underlying tension between the country's two ethnic groups: the Muslim Azeris and the Christian Armenians. Most of the Armenian population lives in the exclave Nagorno-Karabakh, which is surrounded entirely by the country of Azerbaijan. This underlying tension became full blown violence in the early twentieth century, sparked by 
labor strikes in attempts to cause uprisings in Russia. "Armenians were part of the wealthy establishment...native Azeris, often far less educated, filled many of the jobs in the oil fields, railroad yards, and factories” (LeVine 2007). One of the leaders of the Baku strikes was a young Josef Stalin. Militias attacked oil facilities and refineries under the direction of czarist ministers, hoping to spread confusion among the striking laborers and have them turn on each other. Instead, it only worsened the ethnic tensions. During the 1905 revolution in Russia, Lenin sent lieutenants to lead uprisings in Baku. Czarist authorities did not intervene, and Muslim Azeris massacred local Armenians. Riots raged all over Baku, homes of Armenians burned to the ground, often with the residents prevented from, or shot while, escaping. The violence further spread to the oil fields, resulting in the destruction of many oil facilities. Even over a decade later during the Russian Revolution, Armenian Bolsheviks proved vital in the eventual Red victory in Azerbaijan. Throughout the Russian Civil War, Azeri-Armenian ethnic clashes occurred consistently, with high casualty rates on both sides.

The ethnic strife in the country understandably worried the European and American oilmen. Some believed the Soviet revolution would ultimately sputter, while others had already begun talking of leaving. Initially, local oil barons believed the uprising would fail, but increasingly began to flee. With the Bolshevik victory, those who stayed became targets of communist retribution. Most of those who fled went to Constantinople or Paris. The result was an oil industry that had fallen into complete collapse. Soviet domination of the region left outside investment untenable. However, when production reached historic lows (13\% of pre-WWI levels ${ }^{26}$ ), Lenin had no choice but to seek foreign investment. His New Economic Plan offered small companies to opportunity to privatize. Despite the US trade embargo on Soviet Russia, Lenin was nonetheless able to attract investment interest from European as well as US industries. 
US teams were eventually able to secure numerous contracts and the rights to drill. The Soviet Union was able to negotiate contracts that promised hundreds of millions of dollars in investment fees and even more in loans. One particular contract stated that in exchange for Sinclair Oil access to Baku, Grozny, and a monopoly of the Siberian island of Sakhalin, the US would have to diplomatically recognize the USSR (LeVine 2007). However, after Lenin's death in 1924, Stalin voided all previously established contracts. Stalin would later employ American and European consultants and engineers to help construct huge industrial projects. However, the foreign personnel were hired help, not as profit-earning co-owners. Baku’s oil fields were producing 100 billion barrels by 1930, third highest in the world ${ }^{27}$.

World War II saw the production in Baku slow significantly, as Hitler drove toward the city to capture the fields. Stalin ordered many of the oil well plugged in the event the Nazis reached their destination. After the defeat of Germany, the oil industry soon found the concrete used in plugging the wells ruined many of them. In addition, pumping methods and technology was old and deteriorating. For a time, it appeared Baku would instead become the focus of Soviet refining, until the Soviets began to drill in the Caspian Sea itself. The Soviets dubbed the first off-shore drilling platform “Oily Rocks”, and it became a national attraction. However, drilling in the Caspian proved to be far more difficult than Soviet engineers had anticipated, and the results were underwhelming. The Soviets had already located huge reserves in the Volga River basin and in Siberia and turned most of their attention there.

Production in Azerbaijan continued unabated and without little-to-no foreign investment until the collapse of the Soviet Union. Azeri SSR president Heydar Aliyev, whom had been the first Azeri in the Soviet Politburo, had returned to Azerbaijan. He had been removed from office by Mikhail Gorbachev on corruption charges in 1987, but remained in Moscow until 1990. 
Aliyev had denounced the Communist Party and returned home, reinventing himself as a nationalist. He was elected to the Azeri parliament that year. The Azeri-Armenian war had been fought since 1988. The collapse of the Soviet Union in 1991 caused the violence to surge. Aliyev, who had negotiated a peace treaty between Armenia and his semi-autonomous region of Nakhchivan, was invited to Baku to help with a coup which ultimately led to the overthrow of the Azeri government. Aliyev was able to seize power himself, elected president in October 1993. He immediately sought to end the war, but could not, and was later forced to concede the Nagorno-Karabakh region to Armenian control. He also reopened the oil fields for foreign investment.

Russia immediately claimed they had the rights to the fields since they were discovered and developed during the Soviet era (LeVine 2007). Attempts by the US to expedite the impending deals with several multinationals were met very coolly by their Russian counterparts. In addition, Aliyev himself may have been wavering, since the US was not interested in helping the peace process over the Nagorno-Karabakh war. A proposed plan that offered a $40 \%$ stake of the three biggest Azeri oil fields to the US companies was abruptly scuttled by the Azerbaijanis, and months passed without further talks. After months of tense negotiations between the oil companies and Aliyev, the so-called "Deal of the Century” was signed on September 20, 1994. The Russians declared they did not recognize the deal even before the parties had left the palace. Aliyev asked US President Bill Clinton to talk to Boris Yeltsin to be flexible, but the Russian had shifted their interests to the pipelines the oil flowed through. 


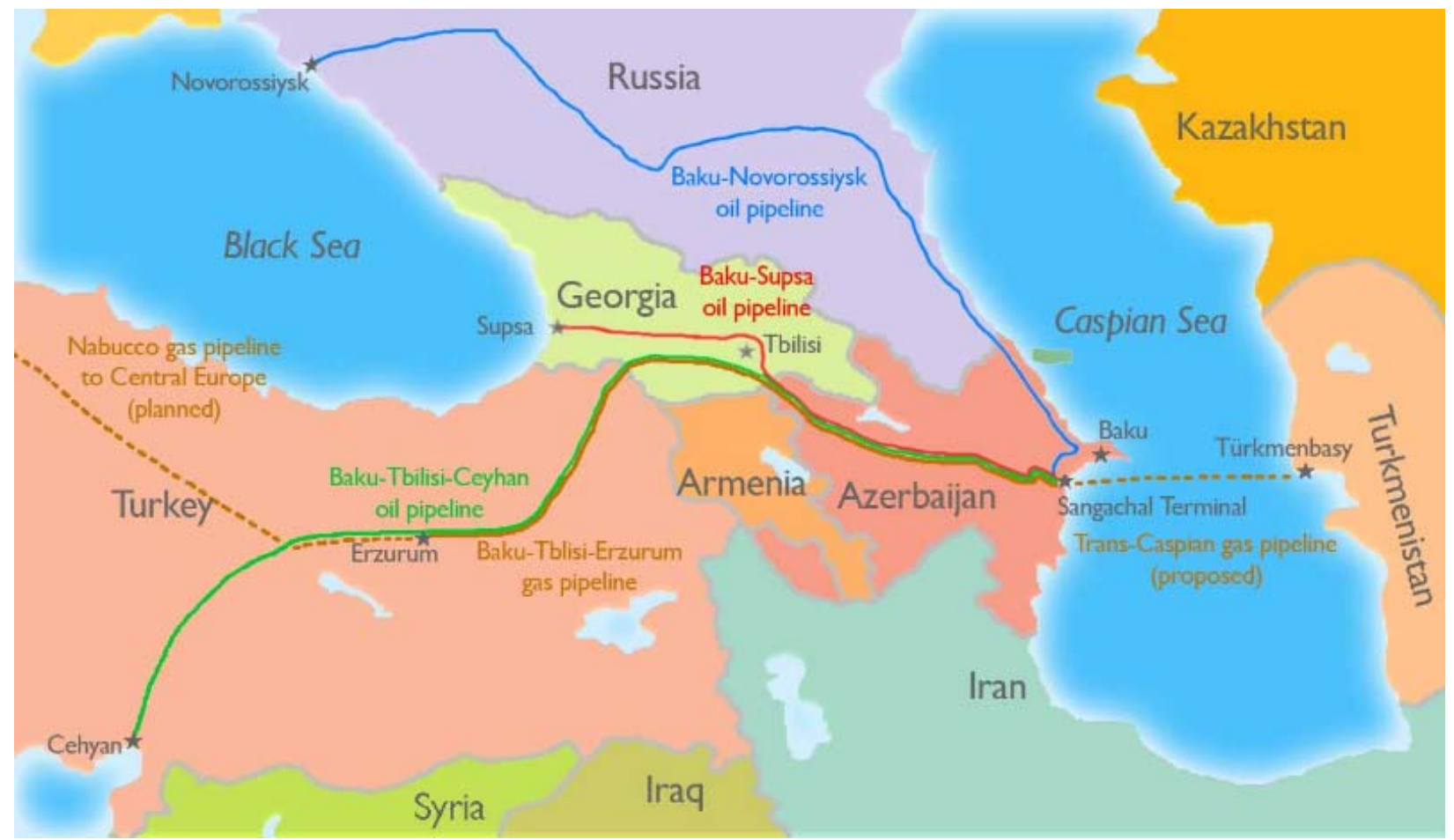

Figure 4: Baku Pipelines, Current and Proposed (The BTC is in green) ${ }^{28}$

Azerbaijan now dealt with the transportation of the oil out of the country. It had three viable options. The first was the Baku-Tbilisi-Ceyhan (BTC) pipeline which had great risk/reward potential (see Figure 4). If it was successful, it would break Russia’s pipeline monopoly, cement political support from Georgia, Turkey, and the United States, and open markets in Western Europe. Conversely, retaliation from Moscow would be guaranteed, and the pipeline would be open to Armenian and Kurdish sabotage which would cause fees to escalate (Stulberg 2007). The second option involved refurbishing the Baku-Suspa pipeline, which runs from Baku to Georgia’s Black Sea coast. This would be the cheapest option, as well as the shortest. It would also open up Western European markets, all while bypassing Russian territory. However, it would receive tepid endorsement from the US and Turkey. Worse, neither country 
would offer security guarantees, while at the same time antagonizing Russia. The pipeline would also run through at least four potential conflict zones in the Caucasus.

The third option was utilizing Russian controlled pipelines to the north and into Europe. Its advantages were keeping Russia pleased as well as offering Baku the opportunity to ship high volumes of oil early with the Baku-Novorossiysk pipeline. The disadvantage to this option was provoking both Turkey and the US, as well as raising costs of transportation. "Some compared the events that would follow with the Great Game between Britain and imperial Russia...this time, the US, Britain, and Turkey would be pitted against Russia and Iran” (LeVine 2007). The US developed a plan with two parts. The first involved a massive expansion of NATO, stopping at Ukraine and Belarus, and secondly, the Caspian states would have control of their lands, free of Russian influence. Ultimately, it took until 2002 for Azerbaijan to select the BTC pipeline option. Due to years of negotiations, talks, cancelled plans, and other hold-ups, Azerbaijan was able to defy the Russians. Internal politics and rivalries inside Russia caused enough problems on their own to weaken Russia long enough for Azerbaijan to proceed with the BTC project.

Azerbaijan is an excellent example of accumulation by dispossession and hegemonic conflict in the Caspian region. The country has long seen foreign investment in its oil reserves, but since the end of the Soviet Union it has become a site of constant conflict between major powers. The US and Russia have been locked against each other for the oil there since 1991. The struggle for pipelines is again a classic example of this. Whoever controls the pipelines can dictate the policy of Azerbaijan as well, an argument which extends all the Caspian states. Hegemonic foreign policy has had a considerable impact on the uneven development of this country. 


\section{Kazakhstan}

Kazakhstan has experienced the most significant development since the end of the USSR. It has the largest territory and, more importantly, vast amounts of mineral and energy resources, by far the largest among the Caspian states. This has translated into a continuous hegemonic struggle for energy access for all of the Big Three since 1991. Kazakhstan was the last of the Soviet Republics to declare independence. The president, Nursultan Nazarbayev, has been in office since independence, and was also the chairman of the Kazakh SSR before the collapse of the Soviet Union. Nazarbayev has helped further the foreign investment into Kazakhstan, and is known for his personal handling of energy issues. He has made it a point of emphasis to expand the oil industry as much as possible, and to open it to as much foreign investment as possible. He has made it a goal to move Kazakhstan into the top-50 GDP producing countries in the world (LeVine 2007). As of 2009, Kazakhstan's GDP ranked $56^{\text {th }}$ in the world ${ }^{29}$.

However, he is not without his share of criticism. He has been linked to numerous corruption charges, the most notable being “Kazakhgate”. Nazarbayev had accepted almost \$80 million in bribes from American oil advisor Jim Giffen, which led to Giffen’s arrest in 2003. The deal centered around Giffen, representing several Western oil companies, paying the Kazakh president and several other top aides into securing rights to the Kashagan oil field. Nazarbayev has also been accused of framing political opponents, including the arrest and exile of his son-inlaw. Additionally, in 2006, two of his top political rivals were found dead in separate incidents.

None of this had mattered to the capitalists who have sought the country's resources. Kazakhstan had been an oil producer during the Soviet era, but not nearly as important as Azerbaijan or the Siberian fields. The discovery of the Tengiz oil field in 1979 on the northwestern shores of the Caspian offered a massive opportunity for international investment. In 
the years leading up to and after the Soviet collapse, major debate raged over how and who would be granted access to as well as the shipping rights to the field. The field itself had proven extremely difficult to drill as pockets of hydrogen sulfide gas, dubbed "sour gas", lay above the oil bed. Sour gas is "one of the most insidious naturally occurring substances on the planet, destroying one’s sense of smell before rapidly paralyzing or killing its victim” (LeVine 2007). This gas is also known to dissolve steel.

The Soviets had explored the option of allowing Western oil companies access to drilling, as Chevron had developed a method of containing the sour gas, but each attempt at this was ultimately voided by the Russians. American interest in the region was always resisted. The CIA reported that Tengiz had an estimated 18 billion barrels of oil, and was critical to future Soviet energy needs (ibid.). In addition, the North Caspian itself had the potential of 50 billion barrels (ibid.). It appeared for a while that Chevron, which had courted Soviet officials, would be granted the right to Tengiz. However, BP was working with the Kazakh government, hoping to reach a deal of their own. BP hedged its bets on Nazarbayev. Eventually, Chevron and the Soviet government forced BP to step down, as the Russians promised that even if they drill in Tengiz, BP would never receive Soviet help in transportation. Nazarbayev was understandably disappointed, but knew Tengiz was the key to distancing Kazakhstan from Moscow. He did not have to wait long. In October 1990, the Kazakh parliament, following leads from the other Soviet republics, declared itself independent. By the end of the following year, the USSR had been dissolved. Tengiz was immediately reopened to foreign investment. The next two years involved negotiations between the US, European countries and oil businesses, as well as Russian and Chinese interest. The final deal, signed in April 1993 divided Tengiz among Chevron (50\%), 
ExxonMobil (25\%), Kazakhstan’s state-own KazMunayGas (20\%), and Russia’s LukArco(5\%) $)^{30}$

The deal exposed the pipeline issue. For decades, Kazakhstan had exported its oil through an aging Soviet network. The new deal would require a new pipeline system. Chevron was hesitant, and Kazakhstan lacked the capital to build it themselves. Russia became an immovable object in the construction negotiations, saying whatever territorial offers were made as insufficient. Rounds of tense and frustrating talks ensued over the next several years. Every time a deal seemed to be within reach, another issue would arise. By 1996, a deal had finally been reached, and the Caspian Pipeline Consortium (also called the Tengiz Pipeline Consortium) was reestablished. The Caspian Pipeline Consortium was initially created in 1992, but after the years of delays, was restructured to include all of the parties. The deal involved eight different oil companies from the US, Great Britain, the Netherlands, and Russia. The pipeline began operations in 2001.

The Kashagan oil field was a potential blockbuster, and was first noticed by the Soviets (see Figure 5). In 1990, BP was allowed to begin initial studies of the Soviet data, which suggested a massive geological structure under the Caspian Sea. Seismic mapping was completed in 1997, and by then the consortium interested in drilling the potential field had grown to nine corporations from four different nations: the US, France, Britain, and Japan. The oil field was projected to have 15 billion barrels of crude, possibly more. Drilling in the north Caspian is difficult and unique (see Figure 6). Some areas of sea were just ten feet deep above the Kashagan, and ice flows were common during winter. This proved to be one of many problems that delayed the drilling process. Construction on the oil platform ran over a year behind schedule, but in July 1999 it was put online despite not being completed yet. Drilling took over a 
year to progress through the salt dome over the potential oil, and tensions among the Kazakhstani government and the consortium rose. However, as the drilling went deeper, it meant the possibility of a massive find.

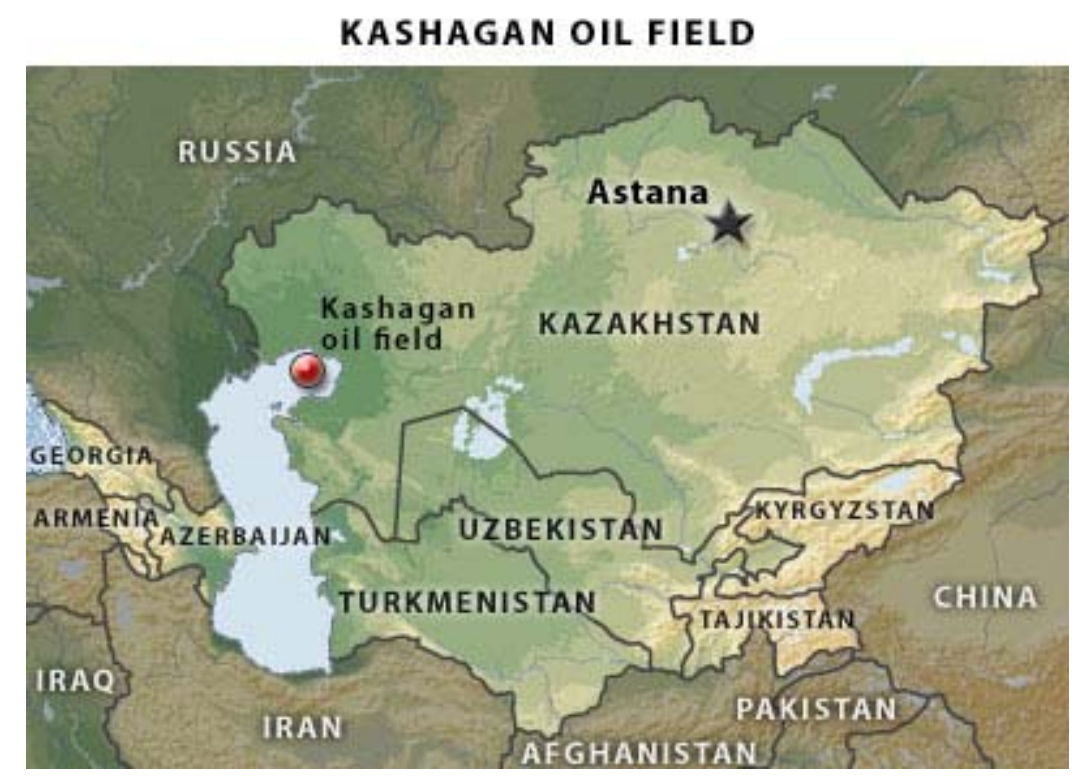

Figure 5: The Kashagan Oil Field ${ }^{31}$

The evidence of the potential of Kashagan meant another series of pipelines would be needed to carry the oil. The US wanted a network to stretch from Baku to Ceyhan, Turkey, which would later become the BTC pipeline. The US's goals were clear: “The pipeline could be routed so as to skirt not only Russia, but also Iran...America and its allies could collect a huge energy dividend” (LeVine 2007). 


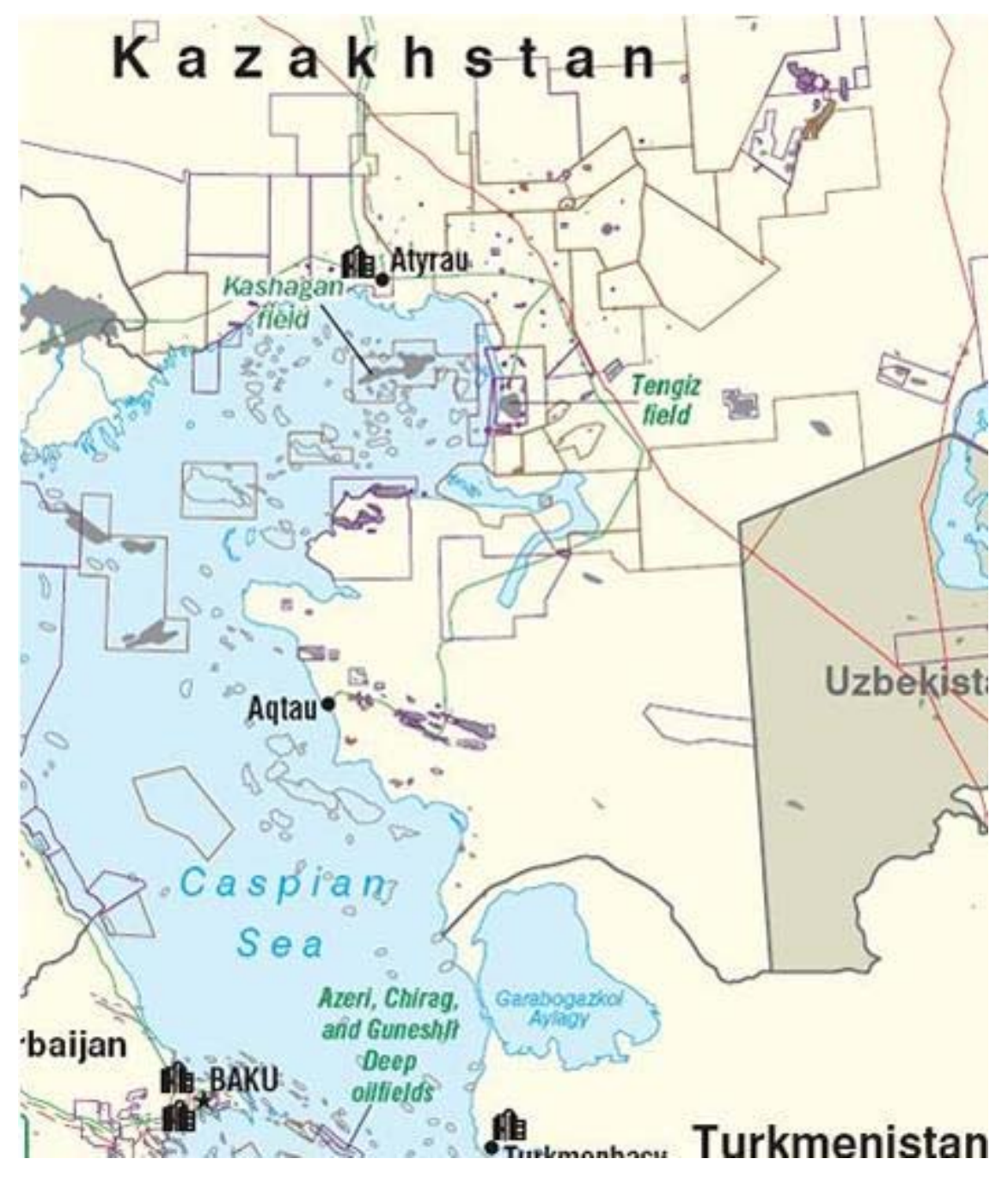

Figure 6: The Site of the Kashagan Oil Field ${ }^{32}$

This created infighting among the oil companies, who wished to pursue a shorter pipeline through Iran to the Persian Gulf, and the US who refused to allow Iran any access. In the end, the US government won. Gradually, the oil companies began to agree to concessions. Several of the Caspian states agreed to the conditions of construction. On November 18, 1999, the governments of the US, Georgia, Azerbaijan, Turkey, and Kazakhstan signed documents to begin the pipeline’s construction. Russia immediately expressed its displeasure with the events, saying both Azerbaijan and Kazakhstan should use existing Russian infrastructure rather than a network 
that doesn't yet exist. Not to be outdone, the Chinese signed an agreement of their own with Kazakhstan for construction of their own pipeline in 1997 (see Figure 7). The pipeline would be built in three separate stages, the first section completed in 2005. The final phase of construction is expected to be finished in $2011^{33}$.

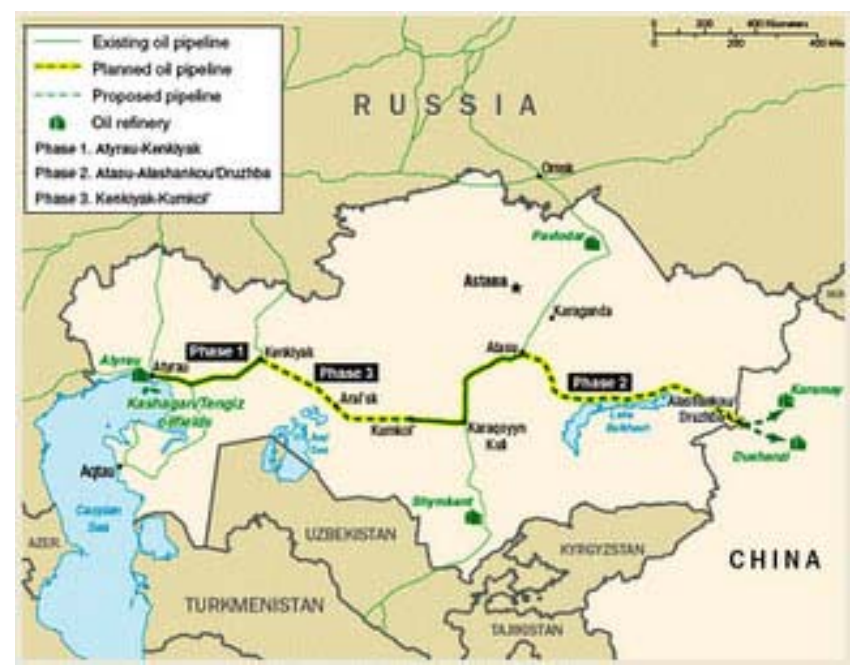

Figure 7: The Kazakh-Chinese Oil Pipeline ${ }^{34}$

Development of the Kashagan oil field has been wrought with problems and delays. The difficultly of drilling the Caspian has proven to be an effective means of drastically altering the field's development. The Kazakh government has also slowed progress. The Kazakh government bought approximately $\$ 1.2$ billion worth of BP's stake in the field in 2003 , after BP attempted to sell their entire stake to two Chinese oil companies. In 2007, the government halted development of the field, citing environmental concerns, and suspended Italian Agip’s contract. After discussions, development was restarted, and Agip was allowed back into the country ${ }^{35}$. Currently, the field is projected to begin full operations in 2014. 
The impact of energy development in Kazakhstan has been considerable. The government unleashed a massive series of spending initiatives with the incoming stream of oil revenue. Western-style stores and restaurants opened in the capital of Alma-Ata. Nazarbayev's most daring move came in 1997, when he moved the capital from Alma-Ata to a town in northcentral Kazakhstan named Aqmola. Aqmola was renamed Astana, literally "Capital”. The move was Nazarbayev's attempt to establish a city of his own, modern and expansive. The move was controversial, as the new capital lay in a remote part of the Kazakh steppe where weather was unpredictable and extreme. The city's development was explicitly funded from the oil revenue. The city's population has more than doubled since the move, to $600,000^{36}$. The capital spent on the construction of Nazarbayev's project often did not make it to the residents of the city. Poverty still was widespread, and continues to be, especially with the financial collapse. The rapid spending, the worldwide drop in energy prices, and the credit crisis resulted in bank failures across the country. The worldwide credit crisis has hit Kazakhstan particularly hard. The Kazakhstani government has taken over 25\% stake in each of the country's four largest banks $^{37}$. In addition, international energy companies have been easing interests in the country. BG and Eni of Italy each have expressed interest in restructuring contracts over the rights to the Karachaganak gas field.

Simultaneously, Kazakhstan has pursued increased cooperation with the United States economically and militarily. Then Vice-President Dick Cheney visited the country in 2006 "to shore up relations with the leader of a country that within a decade was expected to be exporting more than two million barrels of oil a day" (LeVine 2007). Cheney chose not to comment on the human rights record of Kazakhstan. Kazakhstan has also signed strategic partnerships pacts with the $\mathrm{US}^{38}$. 
Kazakhstan is another example of the interrelationship between hegemonic conflict, accumulation by dispossession and uneven development. The Tengiz and Kashagan fields are two of the world's largest oil fields. The actions of the US and Russia in this country gives clear evidence of how these countries plan to pursue their hegemonic goals through energy policy. The Chinese, meanwhile, continue to act more subtlety but have themselves pursued a similar agenda. All three have maneuvered to keep the others out, and all three have employed a policy of dispossession. The consequence has been uneven development. Kazakhstan had been unafraid to secure the best deals possible, and was not afraid to act independently and antagonize the hegemons. The credit crisis has shaken the country, and has abated much of its political and strategic ambitions due to decreased capital and a weakened position to the Big Three. 


\section{CHAPTER 6: CONCLUSIONS}

The Caspian states will continue to be an overlooked region of the world for most, but will only continue to grow in importance to the Big Three. The region offers an incredible amount of natural resources vital to the economies of the US, Russia, and China. In addition, their strategic location only increases their value to the Big Three. The Russians have already spoken out in disapproval of the increased presence the US has taken in the region, and have made attempts to strengthen their own influence. The Chinese have established themselves as willing to give Caspian state governments funds, equipment, and training to build new and expanding infrastructure in exchange for lucrative resource deals.

The actions of the Big Three exemplify Harvey’s conditionality of accumulation by dispossession and Arrighi's theory of neoliberalist expansion. Their continued expansion in the region furthers influence for each. This is also the underlying theme of hegemonic conflict. Each of the Big Three seek goals in the Caspian states, and among them is keeping the others in check. Each has gone about this differently, but the ultimate goal remains the same. In addition, Arrighi's theory of declining hegemonic influence being backed up by military presence is shown through the US’s policy of establishing long-term airbases in Kyrgyzstan. Russian opposition to the construction of a series of new pipelines that would skirt Russian territory supports the conditionality of accumulation by dispossession, and increasing Chinese and American financial aid demonstrate both the spatial fix and hegemonic conflict. This results in the uneven development of the Caspian states. Those with more to offer in terms of resources (Kazakhstan, Azerbaijan, and Uzbekistan) or strategic locations (Kyrgyzstan) have seen their economies receive lucrative aid from the US. Russia continues to treat each of the Caspian states as former members of an empire, and is often the first choice of aid the Caspian states seek. The 
Chinese have taken a different approach, selling goods and supporting construction efforts in exchange for resource access. These are all tools of the spatial fix, and each continues both the hegemonic conflict and uneven development of the region.

This thesis will hopefully contribute to the field of geography by firstly discussing a region of the world most know little about. Further, understanding and analyzing why the world's superpowers have such interest in the region, what their intentions are, and how they pursue those interests will add to the discipline. It will also demonstrate how major figures in human geography in Harvey and Arrighi's conditionalities and theories operate. Understanding hegemonic conflict, the spatial fix, dispossession, and uneven development and using that knowledge to demonstrate what the Big Three are willing to do for their goals furthers research and knowledge of how humans operate in space.

When considering Harvey and Arrighi’s principles, the actions of the Big Three will continue the uneven development of the Caspian states, unless an unforeseen events occur in the future. The Caspian states offer the proper conditions for easing Harvey's spatial fix in the case of the USA and China, as well as Arrighi's theory of hegemonic decline in the cases of Russia and the USA. The leaders of the Caspians states would generally gain the most from the continued hegemonic conflict in the region, however, the citizens of the countries involved face the consequences of successful hegemonic gains. As resource extraction continues, the adaptability of the Caspians states warrants continued attention. Potential focus on the top-down ramifications of policy of the governments of the Caspian states could offer authentic examples of actual improvements; however, in the views of the researcher, this would reveal the real uneven development in the Caspian states. 


\section{REFERENCES}

Bayulgen, O., “Foreign capital in Central Asia: curse or blessing?” Communist and PostCommunist Studies 38 (2005) 49-69

Beyer., J., "'Please invest in our country' - how successful were the tax incentives for foreign investment in transition countries?” Communist and Post-Communist Studies 35 (2002) 191-211

Buttrick, S.C., Moran, J.P., “Russia’s missing link? Social capital, entrepreneurialism, and economic performance in post-communist Russia.” Communist and Post-Communist Studies 38 (2005), 357-368

Cheloukhine., S., King, J., "Corruption networks as a sphere of investment activities in modern Russia,” Communist and Post-Communist Studies 40 (2007) 107-122

Harvey, D., A Brief History of Neoliberalism., Oxford University Press., 2007

Harvey, D., Spaces of Globalism: a Theory of Uneven Geographical Development., Verso Publishing, 2006

Harvey, D., The New Imperialism., Oxford University Press, 2003

Klare., M., Blood and Oil: The Dangers and Consequences of America's Growing Dependency on Imported Petroleum., Holt Paperbacks., 2005

LeVine. S., The Oil and the Glory: The Pursuit of Empire and Fortune on the Caspian Sea., Random House., 2007

Rasizade, A., "Putin's mission in the Russian Thermidor," Communist and Post-Communist Studies 41 (2008) 1-25

Sandole, DJD., "Central Asia: Managing the delicate balance between the 'discourse of danger', the "Great Game”, and regional problem solving." Communist and Post-Communist Studies 40 (2007) 257-267

Shlapentokh, D., “Dugin, Eurasianism, and Central Asia”, Communist and Post-Communist Studies 40 (2007) 143-156

Shlapentokh, V., "Russia, China, and the Far East: old geopolitics or a new peaceful cooperation?”, Communist and Post-Communist Studies 28 (1995) 207-318

Smith, N. Uneven Development: Nature, Capital and the Production of Space., Basil Blackwell, 1991

Smoke and Mirrors (2008, March) The Economist, 386, 27-29 
Solovyey, E.G., “Geopolitics in Russia - science or vocation?” Communist and Post Communist Studies 27 (2004) 85-96

Stulberg, A. N., Well Oiled Diplomacy: Strategic Manipulation and Russia's Energy Statecraft in Eurasia., State University of New York Press., 2007

Tookey, D., “The environment, security, and regional cooperation in Central Asia”, Communist and Post-Communist Studies 40 (2007) 191-208

Tsygankov, A., "Modern at last? Variety of weak states in the post-Soviet world”, Communist and Post-Communist Studies 40 (2007) 423-439 


\section{NOTES}

${ }^{1}$ http://www.lib.utexas.edu/maps/commonwealth.html

${ }^{2} \mathrm{BBC}$

3 "History of Central Asia." Encyclopædia Britannica. 2008. Encyclopædia Britannica Online. 27 Aug. 2008

${ }^{4}$ Eurasianet.org 3/17/08

5 “New update on events in Andizhan” (http://www.gov.uz/en/content.scm?contentId=12614)

6 "Preliminary findings on the events in Andijan"

(http://www.osce.org/documents/odihr/2005/06/15233_en.pdf)

${ }^{7}$ US closes air base in Uzbekistan amid uprising dispute November 22, 2005

(http://www.boston.com/news/world/europe/articles/2005/11/22/us_closes_air_base_in_uzbekist an_amid_uprising_dispute)

8 “Dual power takes power of Kyrgyzstan” 3/22/05 http://www.eurasianet.org/departments/insight/articles/eav032205.shtml

${ }^{9}$ U.S. Helped to Prepare the Way for Kyrgyzstan's Uprising 3/30/05 http://www.nytimes.com/2005/03/30/international/asia/30kyrgyzstan.html

${ }^{10}$ Overnight Violence Halts Bishkek Rallies April 20, 2007 http://www.rferl.org/content/article/1075984.html

${ }^{11}$ Kyrgyzstan Wants U.S. Soldier's Immunity Lifted In Wake Of Shooting December 07, 2006 http://www.rferl.org/content/article/1073268.html

${ }^{12}$ Kyrgyzstan to shut key NATO base 04 February, 200 http://www.russiatoday.com/Top_News/2009-02-04/Kyrgyzstan_to_shut_key_NATO_base.html

${ }^{13}$ China, Kyrgyzstan sign joint statement on enhancing co-op, friendship 8/15/2007 http://news.xinhuanet.com/english/2007-08/15/content_6532960.htm

${ }^{14}$ Human Rights Developments

http://www.hrw.org/legacy/reports/1994/WR94/Helsinki-20.htm

${ }^{15}$ Tajikistan: rising from the ashes of civil war http://www.un.org/events/tenstories_2006/story.asp?storyID=600 
${ }^{16}$ http://www.unodc.org/uzbekistan/en/fact_sheets.html

${ }^{17}$ Rogun Dam a Hot Topic as Tajiks Make it Through Another Winter for Energy Shortages

3/13/09 http://eurasianet.org/departments/insightb/articles/eav031309f.shtml

${ }^{18}$ Chinese To Build Tajik Hydroelectric Plant

http://www.rferl.org/content/article/1074128.html

${ }^{19} \mathrm{http}: / / \mathrm{www}$. dailykos.com/story/2009/2/19/14150/5844

${ }^{20}$ Europe should help Turkmenistan shed light on dead dictator's gas billions http://www.globalwitness.org/media_library_detail.php/595/en/europe_should_help_turkmenista $\underline{\text { n_shed_light_on_dead }}$

${ }^{21}$ https://www.cia.gov/library/publications/the-world-factbook/geos/tx.html

${ }^{22}$ Turkmenistan says gas field in world's top five

http://www.reuters.com/article/rbssEnergyNews/idUSLE64584320081014

${ }^{23}$ Turkmenistan: Frustration Mounts as Western Energy Companies Wait for Ashgabat to Make Up Its Mind

http://eurasianet.org/departments/insightb/articles/eav112408s.shtml

${ }^{24}$ Russia to delay construction of proposed gas pipeline to China http://www.forbes.com/feeds/afx/2008/10/07/afx5522204.html

${ }^{25}$ http://www.redstate.com/skanderbeg/2009/07/16/nabucco-pipeline-project-finally-gets-going/

${ }^{26}$ LeVine 2007

${ }^{27}$ Ibid

${ }^{28}$ http://sudanwatch.blogspot.com/2008/08/sudans-president-says-ready-to-go-to.html

${ }^{29}$ https://www.cia.gov/library/publications/the-world-factbook/geos/kz.html

${ }^{30}$ Tengizchevoil Project

http://www.hydrocarbons-technology.com/projects/tengiz/

${ }^{31}$ http://www.stratfor.com/memberships/119181/analysis/kazakhstan_risks_delaying_kashagan

${ }^{32}$ http://www.energy-pedia.com/article.aspx?articleid=134237

${ }^{33}$ Stulber 2007 
${ }^{34}$ http://silkroadintelligencer.com/2007/09/19/kazakhstans-pipeline-dependence-current-stateand-future-outlook-part-two-china/

${ }^{35}$ Kazakhstan, China agree on pipeline from Caspian

http://uk.reuters.com/article/oilRpt/idUKL1872705320070818

${ }^{36}$ Oil companies on defensive in Kazakhstan 10/10/07

http://www.eurasianet.org/departments/insight/articles/eav101007f.shtml

${ }^{37}$ Kazakhstan's capital holds lavish anniversary celebration 7/9/07 http://www.eurasianet.org/departments/insight/articles/eav070907.shtml

${ }^{38}$ Kazakhstan: IMF praises Kazakhstani bailout plan 11/19/08

http://eurasianet.org/departments/insightb/articles/eav111908a.shtml

${ }^{39}$ Kyrgyz Interim Government Winds Its Way Through Obstacles http://www.eurasianet.org/node/61185 